\title{
SRC Family Gene
}

National Cancer Institute

\section{Source}

National Cancer Institute. SRC Family Gene. NCI Thesaurus. Code C17162.

A family of genes that encode structurally similar non-receptor tyrosine kinases that play a role in intracellular signaling. Mutation of genes in this family is associated with cancer. 